\title{
Shift in the United States Climate Policy and the Arctic Council Agenda ${ }^{1}$
}

\section{A. Sakharov}

Andrei Sakharov - Researcher, Centre for International Institutions Research, Russian Presidential Academy of National Economy and Public Administration; 11 Prechistenskaya naberezhnaya, 119034 Moscow, Russian Federation; E-mail: sakharov-ag@ranepa.ru

\begin{abstract}
Environmental issues form the basis of the Arctic Council's agenda. Since the first Senior Arctic Officials (SAOS) meeting in 1996, issues related to ecology and climate have been raised at almost every event under the aegis of the forum. A substantial number of structures within the forum's institutional framework were created to engage in monitoring exercises and scientific research, as well as to harmonize the positions of Arctic Council members on the most pressing environmental and climate change concerns in the region.

In this regard, the change in the general course of U.S. environmental policy under the administration of Donald Trump could significantly complicate the interaction between members in key areas of the Council's agenda. The United States' withdrawal from the Paris Agreement and the lifting of the moratorium on oil and gas exploitation in the Arctic seabed will certainly impede dialogue within the Council. Nevertheless, there are several aspects of U.S foreign and internal politics which could work to preserve its long-term environmental policy trend despite changes brought about by the Trump administration. Even in the short term, the activities of the U.S. within the Arctic Council and the provisions of the Fairbanks Ministerial Declaration differ from the president's statements on climate change.

The U.S.'s new environmental policy is compared to the priorities of Finland's 2017-2019 chairmanship which maintains the traditional environmental focus of the forum's agenda while intensifying cooperation with other international institutions on climate change issues. Thus, the institutional basis established in previous years, and more importantly, the stable agenda and concrete work by the forum's bodies ensure the effective use and functioning of the Arctic Council. The Finnish presidency and the secretariat of the Arctic Council are not adjusting the agenda to accommodate policy changes of individual members and the working groups have continued their usual activities.
\end{abstract}

Key words: Arctic Council, Paris Agreement, climate change, environment policy, D. Trump

For citation: Sakharov A. (2018) Shift in the United States Climate Policy and the Arctic Council Agenda. International Organisations Research Journal, vol. 13, no 1, pp. 66-79. (In Russian and English.) DOI: 10.17323/1996-7845-2018-01-04

One of the defining factors of international relations in 2017 was the uncertainty resulting from the election of Donald Trump as the president of the United States. This uncertainty affected many areas, such as international security, trade and regional integration institutions. The focus of this article is an analysis of the consequences of

${ }^{1}$ The editorial board received the article in October 2017. 
decisions taken by Donald Trump for the Arctic Council's environment and climate change agenda.

During the active phase of the recent Ukrainian crisis, the Council's ability to reach consensus was called into question by political disagreements among its key members. Nevertheless, despite several isolated incidents such as the boycott of the Council's meetings in Russia by western countries, the institution managed to focus on its core agenda items and reached agreements on multiple solutions and new mechanisms, to be discussed below.

The drastic shift in the U.S. position on environmental and climate change issues, at least at the level of the administration, may work to exclude one of the leading Arctic nations and the largest economy in the world from discussion of the most basic elements of the Arctic Council's agenda. Mr. Trump's statements and his decisions as president show that the new administration can act unpredictably, and may withdraw from key international agreements and institutions without regard for the discontent of the international community and civil society. This paper attempts to analyze the extent to which the new U.S. climate policy will affect the activities of the Arctic Council during Finland's chairmanship in 2017-2019.

\section{The Arctic Council's Environment Agenda}

Environmental protection and combating climate change have been central elements of the Arctic Council's agenda since its inception as an international institution. The adoption of the Arctic Environmental Protection Strategy (AEPS) was one of the early outcomes of the process directly preceding the formation of the Council [Arctic Environmental Protection Strategy, 1991]. At a meeting of representatives from Arctic states in September 1989, the parties primarily focused on environmental and climate issues faced by the region and the ways to tackle them.

The AEPS was adopted in 1991 as part of the preparatory work for the first meeting of ministers from Arctic states, and provided for cooperation between the parties in areas such as scientific research, environmental monitoring, human impact assessment and the control and reduction of pollutants. Thus, the AEPS laid a groundwork for the future activities of the Arctic Council on climate and environment. In addition, the document largely determined the institutional structure of the forum - it provided for the establishment of the Arctic Monitoring and Assessment Programme (AMAP), the mechanism for the Protection of the Arctic Marine Environment (PAME), the Conservation of Arctic Flora and Fauna Working Group (CAFF) and the Emergency Prevention, Preparedness and Response Working Group (EPPR), all of which eventually became leading working bodies of the Arctic Council.

Environmental issues remained at the core of the Council's activity alongside such issues as search and rescue cooperation and the socioeconomic development of the circumpolar territories. Since the first Senior Arctic Officials (SOAs) meeting was held in 1996, ecology and climate have been discussed at almost every event under the aegis 
of the forum. At their first meeting in Iqaluit (September 1998) chaired by Canada, the ministers agreed upon several commitments in the field of Arctic environmental protection. In particular, the Sustainable Development Working Group (SDWG) was established, which included senior officials and representatives of permanent member organizations. The participants also began the work on the implementation of the Arctic Council Action Plan to Eliminate Pollution of the Arctic (ACAP) [Arctic Council, 1998].

The 2000s saw the establishment of the institutional framework for further development of environmental issues within the Arctic Council, with the creation of such bodies/projects as: the Arctic Contaminants Action Program (ACAP), the Arctic Monitoring and Assessment Programme (AMAP), the Arctic Climate Impact Assessment (ACIA) and the Task Force on Short-Lived Climate Pollutants. These entities formed the primary workflows within the Arctic Council arranged around the following topics: reduction of pollutant emissions, emergency response and preparedness, climate change processes monitoring and research of underlying anthropogenic factors.

\section{United States' Climate Policy under the Obama Administration}

The United States, in view of objective geo-political and economic factors, is one of the key members of the Arctic Council. The United States has chaired the Arctic Council twice: in 1998-2000 and in 2015-2017.

In the framework of its first chairmanship the United States promoted the launch of the Arctic Climate Impact Assessment (ACIA) project which became the key mechanism for cooperation among Arctic countries in the field of climate change research in the region. ${ }^{2}$

During the second Council chairmanship in 2015-2017, the United States prioritized economic development and improvement of living conditions of the population of the Arctic region, sea route safety and mitigation of the climate change impacts on the Arctic ecosystem. The U.S. chairmanship's overarching theme was "One Arctic: Shared Opportunities, Challenges and Responsibilities." The first meeting of SAOs under the American chairmanship was held on 16-17 June 2015 in Washington. The participants set the agenda priorities for the next two years, and discussed ways to further improve the effectiveness, scope and inclusiveness of the Council's activities. ${ }^{3}$

During the period, the United States in close cooperation with Russia sponsored the Agreement on Enhancing International Arctic Scientific Cooperation in the Arctic - an international instrument aimed primarily at deepening collaboration between scientists involved in research on climate processes. [Arctic Council, 2017b]. Among other results of the two-year chairmanship in the field of environment and climate

${ }^{2}$ United States and the Arctic Region. Arctic Council. Available at: https://www.arctic-council.org/index.php/en/about-us/member-states/united-states-of-america (accessed 7 November 2017).

${ }^{3}$ U.S. Chairmanship of the Arctic Council. U.S. Department of State. Available at: https://www.state. gov/e/oes/ocns/opa/arc/uschair/ (accessed 7.11.2017). 
were: the update of the Snow, Water, Ice, Permafrost in the Arctic (SWIPA) study conducted within the AMAP, the Summary of Progress and Recommendations on black carbon and methane emissions, the Arctic Marine Biodiversity Report (SAMBR) and the Arctic Resilience Action Framework (ARAF).

The ARAF, adopted at the meeting of SAOs on 8-9 March 2017, contains a set of guidelines and key priorities for the activities aimed at ensuring resilience of the Arctic communities and infrastructure to climate change ramifications in several main areas: analyzing and understanding risk and resilience in the Arctic; building resilience and adaptation capacity; taking measures to strengthen sustainability; implementing measures that build resilience through policy, planning and cooperation; and encouraging investment to reduce risk and build resilience [Arctic Council, 2017].

During the presidency of Barack Obama, the United States promoted the intensification of global efforts to combat climate change within the Arctic Council, other international institutions and domestically.

It was under the Obama administration that the United States elevated the status of its representation in the Arctic Council to a truly ministerial level - at the 2011 meeting in Nuuk, the United States was represented by Secretary of State Hillary Clinton. Previously, including during the country's chairmanship of the Council in 1998-2000, the U.S. delegation was headed by the deputy secretary of state.

Climate change, the need to study and monitor related processes and the adaptation of Arctic communities thereto were among the central concepts within the framework of the current Arctic policy strategy of the United States.

The National Strategy for the Arctic Region, adopted in May 2013, regards interaction and participation in the activities of the Arctic Council as instruments for promoting U.S. national interests in the Arctic. The document highlights the important role of the Agreement on Cooperation on Aeronautical and Maritime Search and Rescue as well as the Agreement on Cooperation on Marine Oil Pollution, Preparedness and Response in deepening cooperation among the Arctic states [President of the United States, 2013].

President Obama's administration was active in implementing the strategy. In January 2014, the Implementation Plan for the National Strategy for the Arctic Region was published. One of the key principles of the plan was to ensure that U.S. policy actions were carried out in accordance with the provisions of the Executive Order on Preparing the United States for the Impacts of Climate Change [President of the United States, 2014].

In January 2015, a progress report on the implementation of the strategy was issued. The second part of the report, devoted to the development of responsible governance in the Arctic region, touched upon many issues related to ensuring the environmental sustainability of the northern territories and the U.S. coastal waters and exclusive economic areas. Among the activities aimed at achieving this goal the report listed: conservation of the Arctic ecosystems; enhancement of oil spill prevention systems; implementation of integrated management systems to ensure the coherence of 
economic development with environmental protection goals; creation of the meteorological stations network; and promotion of scientific research in the region. The third part of the report focuses on the development of cooperation among Arctic Council countries and the implementation of specific commitments adopted within the framework of the forum [President of the United States, 2015].

Domestically, the Obama administration made a number of decisions that prioritized the goals of environmental protection and combating climate change in the Arctic region. According to President Obama's Climate Action Plan, the 44th U.S. president considered addressing climate change to be a "moral obligation" for future generations. $^{4}$

On 16 December 2014, President Obama exercised his right under Section 12A of the 1953 Continental Shelf Law to designate the waters of Bristol Bay (the Bering Sea, coast of Alaska) off limits to oil and gas leasing. ${ }^{5}$

A similar step was taken by the outgoing president on 20 December 2016, a few weeks before the end of his term. The Statement on Actions in the Arctic and Atlantic Oceans announced by the president declared $98 \%$ of the U.S. Arctic waters (the Chukchi Sea, the Beaufort Sea) and the shelf area in the Atlantic Ocean "indefinitely off limits to future oil and gas leasing."6

\section{U.S. Climate Policy under the Administration of D. Trump}

The results of the election of the U.S. president in 2016 affected the official position of the U.S. on climate change and environment issues in a major way. Unlike Barack Obama, Donald Trump prioritized immediate economic growth and employment goals over environmental considerations and possible outcomes for future generations. He repeatedly expressed his opinion on the ecologically oriented decisions of the democratic administration as being harmful for domestic economic interests and job creation. In addition, one of the key pillars of his economic development programme is the development of the primary sector, including coal and hydrocarbon extraction capacities.

Mr. Trump's energy policy document “America First Energy Plan” implies the abolition of a number of regulatory mechanisms, including those adopted during the presidency of Barack Obama. In particular, it plans to abolish the Climate Action Plan and the U.S. Water Act on the grounds that they impose unreasonable restrictions on energy companies. Energy development is perceived by the new administration as an

${ }^{4}$ Fact Sheet: President Obama's Climate Action Plan. President of the United States. Available at: https://obamawhitehouse.archives.gov/the-press-office/2013/06/25/fact-sheet-president-obama-s-climateaction-plan (accessed 7 November 2017).

${ }^{5}$ President Obama Protects Alaska's Bristol Bay from Future Oil and Gas Drilling. President of the United States. Available at: https://obamawhitehouse.archives.gov/the-press-office/2014/12/16/presidentobama-protects-alaska-s-bristol-bay-future-oil-and-gas-drillin (accessed 7 November 2017).

${ }^{6}$ Statement by the President on Actions in the Arctic and Atlantic Oceans. President of the United States. Available at: https://obamawhitehouse.archives.gov/the-press-office/2016/12/20/statement-president-actions-arctic-and-atlantic-oceans (accessed 7 November 2017). 
instrument for ensuring national security through achieving energy independence from the OPEC countries and "other countries hostile to the national interests of the United States."7

Before the presidential nomination and during the election campaign, Donald Trump repeatedly expressed doubts about the very concept of climate change and anthropogenic impacts on the environment. In particular, in November 2012, he published a tweet in which he described climate warming as a concept created in the interests of China to reduce the competitiveness of American industry. ${ }^{8}$ This level of skepticism by the president regarding the core concept of the Arctic Council's agenda (as well as those of other international institutions) calls into question the prospects of U.S. participation in circumpolar cooperation on climate issues.

On 28 April 2017, Donald Trump signed an order lifting restrictions on the extraction of hydrocarbons in the waters of the Arctic, Pacific and Atlantic Oceans, including the Gulf of Mexico. This order abolished a number of decisions made by the previous administration, including with respect to the Arctic region.

On 1 June 2017, President Trump announced the withdrawal of the United States from the Paris Agreement of the United Nations Framework Convention on Climate Change (UNFCCC). The president justified his decision by the need to safeguard the interests of American industry and workers, as well as to reduce the costs to American taxpayers associated with the implementation of the objectives under the agreement. Mr. Trump also announced the termination of payments to the Green Climate Fund. [President of the United States, 2017] The U.S. withdrawal from the Paris Agreement raised concerns about the prospects for the agreement itself and international efforts in the field of combating climate change in general.

A few days before the official announcement of this decision at the $\mathrm{G} 7$ summit in Taormina, all G7 leaders except for Trump expressed their commitment to the implementation of the objectives of the Paris Agreement [Group of Seven, 2017]. Similarly, the United States abstained from supporting the G20 Climate and Energy Action Plan at the Hamburg summit [Group of Twenty, 2017]. Thus, the position of the United States has led to the erosion of the traditional consensus among the members of informal global governance institutions on climate change issues.

At the same time, there is a formal aspect to the U.S. withdrawal from the agreement that may be of interest. According to the provisions of Article 28 of the document, the termination of the participation of a signatory and ratifying party to the agreement is only possible four years after its entry into force (three years before a country can withdraw and another year before the decision takes effect), that is, on 4 November 2020 [UNFCCC, 2015]. Thus, preliminary results of the next U.S. presidential elec-

${ }^{7}$ Energy \& Environment. President of the United States. Available at: https://www.whitehouse.gov/ america-first-energy (accessed 7 November 2017).

8 @realDonaldTrump. Donald J. Trump. Available at: https://twitter.com/realdonaldtrump/status/265895292191248385 (accessed 7 November 2017). 
tions may be announced even before the date the United States can formally stop all participation in the Paris Agreement.

Despite the presidential decision, the commitment to the international goals of combating climate change at the level of U.S. federal and state administrations, as well as in the academic and segments of the business community, remains strong. In response to Trump's decision to withdraw from the Paris Agreement, the governors of the states of New York, Washington and California announced the creation of the U.S. Climate Alliance, a bipartisan coalition of states that seeks to implement the goals of the agreement and, in particular, to reduce greenhouse gas emissions. To date, the alliance includes 15 states, the District of Columbia and Puerto Rico. ${ }^{9}$ The coalition is gradually acquiring rudimentary institutional features. The intention to create a single online coordination platform was announced, alongside a self-accountability mechanism in the form of annual progress reports. The first of these reports was released in September 2017 [US Climate Alliance, 2017].

In November 2017, the Climate Science Special Report was released. The document was the product of a close collaboration of 13 U.S. federal agencies in accordance with the Global Change Research Act of 1990. According to the report's findings, there is a high probability that the anthropogenic factor, in particular greenhouse gas emissions, is the main trigger of global climate change. One chapter of the report is devoted specifically to the Arctic region, in particular Alaska. The paper contains conclusions about the relationship between warming in the Arctic and extreme weather events in the contiguous United States. It is noted that warming in the region proceeds at a rate twice that of the world average, which affects the state of the ice cap in the Arctic Ocean and glaciers on land. ${ }^{10}$

The decisions made in the framework of U.S. participation in the work of the Arctic Council during Trump's presidency, coinciding with the final few months of the U.S. chairmanship of the forum, largely contradict the new course of climate policy outlined in the statements and decisions of the current president.

In contrast with the situation that has developed within the G7 and G20, at Fairbanks the members of the Arctic Council, without any reservations about U.S. participation, recognized that "the Arctic is warming at more than twice the rate of the global average." The impact of climate change on the Arctic marine environment was also noted. The ministers agreed to continue cooperation in assessing the extent of this impact, as well as on the development of sound management of the marine environment and the implementation of adaptation activities [Arctic Council, 2017c].

At the Fairbanks meeting the ministers adopted the first collective progress report of the Arctic states containing specific recommendations to reduce black carbon and methane emissions. One of the key elements of the report is the goal of achieving

${ }^{9}$ States United for Climate Action. United States Climate Alliance. Available at: https://www.usclimatealliance.org/ (accessed 7 November 2017).

${ }^{10}$ Climate Science Special Report. Fourth National Climate Assessment. Available at: https://science2017.globalchange.gov/ (accessed 7 November 2017). 
a $25-33 \%$ reduction of 2013 emission levels by 2025 . The report outlined priority sectors requiring actions to achieve this goal: diesel powered mobile sources; oil/gas methane leakage, venting and flaring; residential biomass combustion appliances and solid waste disposal [Arctic Council, 2017d]. The ministers also approved the Arctic Resilience Action Framework, designed "to track suggested circumpolar resilience priorities and to coordinate such efforts" [Arctic Council, 2017c].

The Fairbanks Declaration also noted the entry into force of the Paris Agreement and the need for its implementation, including actions related to reducing emissions of long-lived greenhouse gases and short-lived climate pollutants - a topic that was actively developed during previous chairmanships [Arctic Council, 2017c].

During the American chairmanship, the Framework for the Circumpolar Expansion of the Local Environment Observer Network was adopted. The document contains recommendations aimed at creating and expanding a network of local stations for monitoring the state of the environment, primarily in Alaska and Canada, as well as in Scandinavian countries at a later stage [ACAP, 2017].

Thus, taking into account the large number of adopted documents and the designated goals in the field of combating climate change, it can be noted that the sharp turn in the U.S. position on climate change had virtually no practical impact on the final period of the U.S. chairmanship in the Arctic Council, nor on the decisions taken at the ministerial meeting in Fairbanks.

Nevertheless, the press received a preliminary version of the Fairbank Declaration of 9 May 2017, indicating that on the eve of the summit the United States made significant changes to the text of the document, related to the wording on climate change and global warming. The changes proposed by the United States were aimed at softening the wording regarding the risks associated with climate change in the Arctic region. Some of the more direct commitments planned to implement the Paris Agreement were also avoided at the behest of the U.S. delegation. The passage on the threat of the complete disappearance of the Arctic ice cap in summer periods within the next two decades was dropped entirely. ${ }^{11}$

In many ways, the ministerial meeting in Fairbanks, chaired by U.S. Secretary of State Rex Tillerson, demonstrated the achievements of the previous, democratic administration. All the preparatory work for the chairmanship of the Council and for the development of joint decisions, including a legally binding agreement on strengthening international scientific cooperation in the Arctic, was carried out in 2014-2016. In addition, the results of the U.S. chairmanship, even as expressed in the "softened" version of the declaration, do not reflect the general direction of the country's new climate policy.

Despite dramatic changes in approach at the highest level of the country's leadership, the U.S. retains the ideological, conceptual and institutional prerequisites for

${ }^{11}$ Leaked Draft Shows How U.S. Weakened Climate Change Wording in the Arctic Declaration // Inside Climate News. Available at: https://insideclimatenews.org/news/18052017/arctic-council-climate-changerex-tillerson-donald-trump (accessed 7 November 2017). 
returning to the traditional course of its climate policy, in line with ongoing international efforts. First, a significant part of the public, academic and business communities expressed disagreement with Trump's policy and their intention to comply with the country's climate obligations. Second, the conceptual documents of the Obama period, in particular the National Strategy for the Arctic Region, remain in force and contain provisions directly contradicting Trump's policy. Third, even federal executive bodies and dedicated agencies retain a significant number of employees who adhere to the concept of climate change as established by the scientific community, as evidenced by the results of the Climate Science Special Report.

In many ways, the question of a return to traditional climate policy may be directly linked to the success of the current U.S. president's economic policies, to which Mr. Trump chose to link his decisions on climate and environment.

\section{Priorities of the Finnish Chairmanship of the Arctic Council (2017-2019)}

Environmental issues remain at the core of the Arctic Council's agenda under Finland's chairmanship. Finland's Chairmanship Program for the Arctic Council, published in May 2017, specifically singles out the need for joint efforts in the region to promote the goals of the Paris Agreement. In addition, Finland plans to work toward the implementation of the 2030 Agenda for Sustainable Development adopted by the UN in 2015, noting its relevance to the Arctic region. ${ }^{12}$

Environmental protection comes first among the priorities outlined in the Chairmanship Program. Finland calls upon the Council members to focus on biodiversity conservation and pollution prevention, as well as disseminating information and best practices in these areas among themselves and within other intergovernmental forums. ${ }^{13}$

The implementation of the Paris Agreement is prioritized by the Finnish chairmanship as the leading framework for the efforts of the Arctic states in the field of combating climate change in the region. Emphasis is placed on the implementation of the Framework for Action on Black Carbon and Methane adopted by the Council in 2015 which will provide support to efforts taken under the Paris Agreement. The Finnish chairmanship will contribute to the advancement of climate research in the region and the integration of results into the work of UNFCCC mechanisms, as well as to ensuring the coherence of the Council's work on short-lived pollutants with the similar efforts of the United Nations Economic Commission for Europe on the implementation of the Convention on Long-range Transboundary Air Pollution. ${ }^{14}$

${ }^{12}$ Finland's Chairmanship of the Arctic Council in 2017-2019. Ministry of Foreign Affairs of Finland. Available at: http://formin.finland.fi/public/default.aspx contentid $=356546 \&$ nodeid $=50020 \&$ contentlan $=2$ $\&$ culture $=$ en-US (accessed 7 November 2017).

${ }^{13}$ Ibid.

${ }^{14}$ Ibid. 
In order to support activities for the implementation of the Paris Agreement and the Aichi Biodiversity Targets, a meeting of environment ministers will be organized during the Finnish chairmanship. In addition, Finland will host the Second Arctic Biodiversity Congress, where participants are expected to discuss the results of the implementation of the recommendations on the biodiversity assessment process in the Arctic conducted in 2013.

The second priority of the Finnish chairmanship is the development of communication technologies, network accessibility and digital services in the Arctic region. Work in this area involves the creation of new information and communications technology infrastructure, the launch of new communication satellites and the construction of broadband access lines in the Far North. The implementation of these activities is designed to meet the needs of Arctic residents (including indigenous peoples of the North), tourists, sailors and scientists.

Maintaining scientific research facilities and personnel in the region is an important component of the environmental agenda of the Arctic Council. The Finnish chairmanship singles out cooperation in the field of meteorological research as the third priority area of circumpolar cooperation for the upcoming years. Members of the Council are called upon to strengthen scientific cooperation with the World Meteorological Organization. The quality of meteorological studies in the polar region determines the predictive capabilities of meteorological services on both the daily weather forecasts in the entire northern hemisphere and on the state of the global climate as a whole.

Finally, the fourth priority area of the Arctic Council's agenda in 2017-2019 is the development of education capacities in the region with a special emphasis on the needs of indigenous peoples of the North. The Chairmanship Program provides for the expansion of access to quality education through the creation and strengthening of regional communication networks between educational institutions and specialists in this field. An important role is given to the introduction of digital technologies in educational processes, which will intensify the mechanisms for online education.

On 26 October 2017, the first meeting of SAOs was held under the chairmanship of Finland. In addition to discussing traditional issues on the Council's agenda, such as reducing pollutant emissions and developing education, officials were presented with progress reports by the Council's working groups. The U.S. delegation participated in the work of the committee as normal; information on any reservations on its part was not registered. ${ }^{15}$

During the Finnish presidency, the Arctic Council will intensify cooperation with international institutions on climate issues. On 6 November 2017, during the 23rd Conference of the Parties to the UNFCCC, the Arctic Council held a panel discussion on the impact of climate change in the Arctic on the global environment. This event was the first time that the Council participated in the work of the Conference. Scientific

${ }^{15}$ Arctic Council meets in Finland, Addresses Pollution Prevention and Education. Arctic Council. Available at: https://www.arctic-council.org/index.php/en/our-work2/8-news-and-events/475-sao-oulu-2017-02 (accessed 7 November 2017). 
data on climate change in the Arctic was presented at the meeting, and the participants discussed the impact of these changes on sea levels, biodiversity and other indicators of the state of the global ecosystem.

The results of the meeting between U.S. President Donald Trump and Finnish President Sauli Niinisto on 28 August 2017 are of specific interest regarding the prospects of U.S. participation in the work of the Council on climate change and environment. At the press conference following the meeting, the presidents discussed the problem of black carbon emissions and, according to D. Trump, had "a lot of agreement." 16 Thus, it is obvious that cooperation with the United States and its engagement in the Council's work on climate is possible on specific and concrete agenda items. This way Mr. Trump and his administration will not have to be brought into discussions on the validity of the global warming and climate change concepts, but rather will be engaged in practical cooperation on specialized issues such as, for example, the development of meteorological station networks.

Overall, it can be noted that the Arctic Council will once again manage to maintain its efficiency in this period of global political turmoil. The established institutional framework and, more importantly, the stable agenda and specialized activities of the Council's working bodies are largely isolated from political agendas and thus create a sufficient cushion to support the effective functioning of the forum. The declared priorities under the chairmanship of Finland do not depart from the traditional and basic principles of the Arctic Council's agenda. The chairmanship and the secretariat of the Arctic Council do not seek to make adjustments to the policies of individual members and the working groups continue their usual activities.

Nevertheless, under the current conditions, it is more and more difficult to expect really concrete or breakthrough decisions from the work of the Council. In the field of combating climate change, the Council assumes the role of a regional body responsible for monitoring and coordinating the efforts to implement the Paris Agreement. In a situation where one of the key countries of the region no longer intends to fulfill its obligations under this agreement, the Council will have to look for more streamlined wording for final ministerial declarations and progress reports.

However, the probability remains that the new U.S. climate policy resulting from the so-called "wave of populism" that has swept across Europe and North America in 2017 will end as suddenly as it began - with the arrival of the new presidential administration.

${ }^{16}$ Remarks by President Trump and President Niinistö of Finland in Joint Press Conference. President of the United States. Available at: https://www.whitehouse.gov/briefings-statements/remarks-president-trumppresident-niinisto-finland-joint-press-conference/ (accessed 7 November 2017). 


\section{References}

Arctic Council (2017) Arctic Resilience Action Framework; Cooperating for a More Resilient and Prosperous Arctic Region. Available at: https://oaarchive.arctic-council.org/handle/11374/2009 (accessed 22 January 2018).

Arctic Council (2017b) Agreement on Enhancing International Arctic Scientific. Available at: https:// oaarchive.arctic-council.org/handle/11374/1916 (accessed 07.11.2017).

Arctic Council (2017c) Fairbanks Declaration. Available at: https://oaarchive.arctic-council.org/handle/11374/1910 (accessed 7 November 2017).

Arctic Council (2017d) Framework for the Circumpolar Expansion of the Local Environment Observer Network. Available at: https://oaarchive.arctic-council.org/handle/11374/1942 (accessed 7 November 2017).

President of the United States (2013) National Strategy for the Arctic Region. Available at: https://obamawhitehouse.archives.gov/sites/default/files/docs/nat_arctic_strategy.pdf (accessed 22 January 2018).

President of the United States (2014) Implementation Plan for The National Strategy for the Arctic Region. Available at: https://obamawhitehouse.archives.gov/sites/default/files/docs/implementation plan_for_the_national_strategy_for_the_arctic_region_-_fi....pdf (accessed 22 January 2018).

President of the United States (2015) National Strategy for the Arctic Region Implementation Report. Available at: https://obamawhitehouse.archives.gov/sites/default/files/docs/report_on_implementation_of_the_national_strategy_for_the_arctic_region_....pdf (accessed 22 January 2018).

President of the United States (2017) Statement by President Trump on the Paris Climate Accord. Available at: https://www.whitehouse.gov/the-press-office/2017/06/01/statement-president-trump-parisclimate-accord (accessed 7 November 2017).

Group of Seven (2017) G7 Taormina Leaders' Communiqué. Available at: http://www.g7italy.it/sites/ default/files/documents/G7\%20Taormina\%20Leaders\%27\%20Communique_27052017_0.pdf （accessed 7 November 2017).

Group of Twenty (2017) G20 Hamburg Climate and Energy Action Plan for Growth. Available at: http:// www.ranepa.ru/images/media/g20/2017hamburg/2017-g20-climate-and-energy-en.pdf (accessed 7 November 2017).

UNFCCC (2015) Paris Agreement. Available at: http://unfccc.int/files/essential_background/convention/application/pdf/english_paris_agreement.pdf (accessed 7 November 2017).

US Climate Alliance (2017) 2017 Annual Report Alliance States Take the Lead. Available at: https://static1.squarespace.com/static/5936b0bde4fcb5371d7ebe4c/t/59bc4959bebafb2c44067922/1505511771219/ USCA_Climate_Report-V2A-Online-RGB.PDF (accessed 7 November 2017). 


\title{
Изменения климатической политики США и повестка дня Арктического совета
}

\author{
А.Г. Сахаров
}

Сахаров Андрей Геннадиевич - научный сотрудник Центра исследований международных институтов Российской академии народного хозяйства и государственной службы при Президенте РФ (РАНХиГС); Российская Федерация, 119034, Москва, Пречистенская наб., д. 11; E-mail: sakharov-ag@ ranepa.ru

\begin{abstract}
Экологическая проблематика составляет основу повестки дня Арктического совета. С 1996 г., когда состоялась первая встреча Комитета старших должностных лии в рамках Арктического совета, вопросы экологии и климата поднимались практически на каждом мероприятии под эгидой форума. В рамках структуры института создано множество органов, ориентированных на постоянную работу по исследованиям, мониторингу и согласованию позиций в сфере природоохранной деятельности и борьбы с изменением климата.

В связи с этим изменение общего курса экологической политики США с приходом к власти администрации Дональда Трампа может значительно затруднить взаимодействие стран-членов по ключевым направлениям деятельности Совета. Такие шаги, как выход из Парижского соглашения и снятие моратория на добычу полезных ископаемых в шельфовой зоне, безусловно, не будут способствовать укреплению взаимодействия США с партнерами по Арктическому совету. Тем не менее рассматриваемые в данной статье аспекты американской внутренней и внешней политики формируют предпосылки для сохранения долгосрочного курса экологической политики страны в русле мер, принятых в период президентства Б. Обамы, несмотря на изменения, осуществляемые администрацией Д. Трампа. Даже в краткосрочной перспективе практическая деятельность США в рамках Арктического совета и положения принятой на министерской встрече в Фэрбэнксе декларации расходятся с громкими заявлениями президента по вопросам изменения климата.

Новые установки экологической политики США также сопоставляются с приоритетами председательства Финляндии в Совете в 2017-2019 г2., не только сохранившего традиционную экологическую направленность повестки дня форума, но и активизировавщего сотрудничество с международными организациями по климатической проблематике. Таким образом, созданная в предшествующие годы институциональная основа и, что еще более важно, стабильная повестка дня и конкретная деятельность рабочих органов Арктического совета по конкретным актуальным вопросам региона, в значительной степени изолированным от политической повестки, создают достаточную «подушку безопасности» для поддержания эффективного функционирования форума. Финская сторона и Секретариат Арктического совета не стремятся подстраиваться под изменения политики отдельных стран-членов, а рабочие группы продолжают свою привычную деятельность.
\end{abstract}

Ключевые слова: Арктический совет; Парижское соглашение; изменение климата; экологическая политика; Д. Трамп

Для цитирования: Сахаров А.Г. Изменения климатической политики США и повестка дня Арктического совета // Вестник международных организаций. 2018. Т. 13. № 1. C. 66-79. DOI: 10.17323/1996-7845-201801-04

\section{Источники}

Arctic Council (2017) Arctic Resilience Action Framework; Cooperating for a More Resilient and Prosperous Arctic Region. Режим доступа: https://oaarchive.arctic-council.org/handle/11374/2009 (дата обращения: 22.01.2018).

Arctic Council (2017b) Agreement on Enhancing International Arctic Scientific. Режим доступа: https://oaarchive.arctic-council.org/handle/11374/1916 (дата обращения: 07.11.2017). 
Arctic Council (2017c) Fairbanks Declaration. Режим доступа: https://oaarchive.arctic-council.org/ handle/11374/1910 (дата обращения: 07.11.2017).

Arctic Council (2017d) Framework for the Circumpolar Expansion of the Local Environment Observer Network. Режим доступа: https://oaarchive.arctic-council.org/handle/11374/1942 (дата обращения: 07.11.2017).

President of the United States (2013) National Strategy for the Arctic Region. Режим доступа: https:// obamawhitehouse.archives.gov/sites/default/files/docs/nat_arctic_strategy.pdf (дата обрашения: 22.01.2018).

President of the United States (2014) Implementation Plan for The National Strategy for the Arctic Region. Режим доступа: https://obamawhitehouse.archives.gov/sites/default/files/docs/implementation_plan_for_the_national_strategy_for_the_arctic_region_-_fi....pdf (дата обращения: 22.01.2018).

President of the United States (2015) National Strategy for the Arctic Region Implementation Report. Режим доступа: https://obamawhitehouse.archives.gov/sites/default/files/docs/report_on_implementation_of_the_national_strategy_for_the_arctic_region_....pdf (дата обращения: 22.01.2018).

President of the United States (2017) Statement by President Trump on the Paris Climate Accord. Режим доступа: https://www.whitehouse.gov/the-press-office/2017/06/01/statement-president-trump-parisclimate- accord (дата обращения: 07.11.2017).

Group of Seven (2017) G7 Taormina Leaders' Communiqué. Режим доступа: http://www.g7italy.it/ sites/default/files/documents/G7\%20Taormina\%20Leaders\%27\%20Communique_27052017_0.pdf (дата обращения: 07.11.2017).

Group of Twenty (2017) G20 Hamburg Climate and Energy Action Plan for Growth. Режим доступа: http://www.ranepa.ru/images/media/g20/2017hamburg/2017-g20-climate-and-energy-en.pdf (дата обращения: 07.11.2017).

UNFCCC (2015) Paris Agreement. Режим доступа: http://unfccc.int/files/essential_background/convention/application/pdf/english_paris_agreement.pdf (дата обращения: 07.11.2017).

US Climate Alliance (2017) 2017 Annual Report Alliance States Take the Lead. Режимдоступа: https://static1.squarespace.com/static/5936b0bde4fcb5371d7ebe4c/t/59bc4959bebafb2c44067922/1505511771219/ USCA_Climate_Report-V2A-Online-RGB.PDF (дата обращения: 07.11.2017). 